\title{
Optimization of Biscuit from Pedada Fruit and Purple Sweet Potato Flour
}

\author{
Jariyah *, Ulya Sarofa, Nurul Absyah Wahyuningtyas \\ Department of Food Technology, Faculty of Engineering, Universitas Pembangunan Nasional "Veteran" \\ Surabaya, East Java, Indonesia
}

${ }^{*}$ Corresponding author:

E-mail: jariyah.tp@upnjatim.ac.id

\begin{abstract}
Biscuits are foods made from wheat flour with the addition of other food ingredients. It is made through the process of heating and printing. The characteristics of biscuits are generally determined by their crisp texture. One of its ingredients is Pedada fruit flour (PFF) which has high dietary fiber content. It serves as a complement when added to purple sweet potato (PSP) flour with a high source of anthocyanin and antioxidants. The purpose of this study is to optimize the effect of the proportion between PFF and PSP flour on product quality. The research method used was the Response Surface Methodology (RSM) code. The experimental level values were: $+1,414(17.5: 100)$; +1(15:95); 0(10:90); -1(5:85); and -1,414(2.5:80). Furthermore, the research designs between PSP flour to PFF were: (85:5); (95:5); (85:15); (95:15); (90:10); (90:10); (90:10); (90:10); (90:10); (90:2.5); (90:17.5); (80:10); and (100: 10). The data obtained were analyzed using the Expert Design 10.0 analysis. The results showed that the best treatment was in the proportion of PFF to PSP flour having a value of $(90: 10)$. This produced biscuits with criteria of: $6.18 \%$ of moisture; $2.63 \%$ of ash; $0.87 \%$ of fat; $3.26 \%$ of protein; $2.15 \%$ of crude fiber; $1.65 \%$ of antioxidant; breaking strength $7.43 \mathrm{~N}$; color $\mathrm{L}^{*} 34.0$; color a*17.4; and color $\mathrm{b}^{*} 10.8$. The optimum solution table obtained was level 2.5, and 99.88 for PFF and PSP flour respectively.
\end{abstract}

Keywords: Biscuit, optimization, PFF, PSP flour, RSM

\section{Introduction}

Pedada fruit is a type of pedada fruit that grows abundantly throughout the coastal region of Indonesia. Pedada fruit (Sonneratia caseolaris) as a source of carbohydrates $65.12 \%$, in addition, there is also fat $1.42 \%$, water $79.86 \%$, protein $6.24 \%$, ash $7.08 \%$ and there are several vitamins and minerals (Wicaksono et al., 2019). Jariyah et al. (2013) reported that PFF contains quite high dietary fiber (63.7\%) and has hypo cholesterol and hypoglycemic properties (Jariyah et al., 2014), so it is very potential to be developed into functional food products, such as biscuit products. The results of research on biscuit formulations with PFF substitution have been widely done both with flour from tubers, nuts, and from various kinds of starch, but have not obtained optimal formulations, so it is necessary to optimize the biscuit formula using RSM (Response Surface Methodology ) (Singh \& Yadav, 2018; Al-Ansi et al., 2018).

There are 3 kinds of sweet potato flour used in this study namely white sweet potato, yellow sweet potato, and purple sweet potato. Anthocyanins in purple sweet potatoes as antioxidants capable of capturing free radicals and inhibiting fat peroxidation, the main cause of cell damage and degenerative diseases (Cevallos-Casals \& Cisneros-Zevallos 2002; Suda et al., 2003).

The antioxidant ability of purple sweet potato is 4.6-6.4 $\mu \mathrm{mol}$ equivalent to Trolox/g bb. Purple sweet potatoes are also anti-cancer because they contain selenium and iodine (Li et al., 2019). Yellow sweet potatoes contain vitamin A, B, and vitamin C with potassium of 393mg, as well as white sweet potatoes (Neela \& Fanta, 2019). The optimization of the biscuit formula with the RSM 
method in this study consists of 2 stages. The first stage is to test the organoleptic biscuit products from 3 ratio levels (PFF: white sweet potato flour; PFF: yellow sweet potato and PFF: purple sweet potato flour). The previous research organoleptic test showed that biscuits from PFF: PSP (10:90) produce a product that panelists like. To find out the optimization of the proportion of biscuits than in the second phase in this study will be done optimization of the proportion of biscuits using purple sweet potato (PSP) flour. This study aims to find out the optimum point of biscuit formula by the response surface method of moisture, ash, fat, protein, breaking strength.

\section{Research Method}

Pedada Fruit (Sonneratia caseolaris) flour, were obtained from fishpond Sawahan Village Sidoarjo, East Java. Sweet potato purple, sugar, margarine, baking powder, egg, sodium stearoyl lactylate (SSL), skim powder were also procured were procured from the local market Rungkut Surabaya. Processing of biscuits. For the experimental biscuit, sugar, margarine, egg, SLL, skim powder were weighed, mixed, and added pedada, sweet potato flour for each formulation in the required proportion as per the central composite design (Table 1). The various blends were mixed for 5 min using a hand Mixer (Philips) to the obtained dough of biscuits. The dough was then rolled on a platform and cut into a round shape, and baked at $150-160^{\circ} \mathrm{C}, 7 \mathrm{~min}$, and cooled for $30 \mathrm{~min}$ at ambient temperature and packed in polyethylene packets using a sealing machine, stored at $25^{\circ} \mathrm{C}$ before further analysis. Biscuits of each formulation were analyzed moisture, ash, fat, protein, antioxidant, breaking strength, and color.

Analysis of biscuits. The composition of biscuits was determined by using standard methods according to AOAC (2000). Moisture was determined by oven procedure, fat was determined by soxhlet extraction, protein by Kjeldahl method, ash by gravimetry. Determination of the antioxidant activity of the sample was done by 1, 1-Diphenyl-2-picryl-hydroxyl (DPPH) inhibition method as suggested by Nishino et al. (2000). Breaking strength was determined by Singh et al., (2015).

Tabel 1. Design experiment

\begin{tabular}{cccc}
\hline Proportion & & \multicolumn{3}{c}{ Code variable } \\
\hline Sweet Potato & Pedada & $\mathbf{X}_{\mathbf{1}}$ & $\mathbf{X}_{\mathbf{2}}$ \\
\hline 85 & 5 & -1 & -1 \\
95 & 5 & 1 & -1 \\
85 & 15 & -1 & 1 \\
95 & 15 & 1 & 1 \\
90 & 10 & 0 & 0 \\
90 & 10 & 0 & 0 \\
90 & 10 & 0 & 0 \\
90 & 10 & 0 & 0 \\
90 & 10 & 0 & 0 \\
90 & 2.5 & 0 & -1.414 \\
90 & 17,5 & 0 & 1.414 \\
80 & 10 & -1.414 & 0 \\
100 & 10 & 1.414 & 0 \\
\hline
\end{tabular}


Statistical analysis. For optimization of the formulation biscuit, a central composite rotatable design (CCRD) based on response surface methodology (RSM) was used. The experiments comprised of 13 trials as presented in Table 1 . The response surface consists of 2 proportion factors, PFF (X1) range from 17.5 to 2.5, PSP Flour (X2), range from 100 to 80. Design Expert 8.0.4 software was used to generate the design of the experiments, to fit the model by multiple regression, and to analyze the response surfaces. Three replications were conducted for each trial of experiments. Optimization was done for moisture, ash, fat, protein, antioxidant, breaking strength, and color of the biscuit.

\section{Results and Discussion Moisture and ash}

The figure1 shows that the moisture will increase when PSP flour is getting higher with the addition of higher PFF. While the moisture will decrease when PSP flour is getting less and more and more PFF. The moisture decreases when adding PFF 8.5 - $17.5 \mathrm{gr}$ because the PSP is a purple component and the function of the purple sweet potato itself as high water absorption. Whereas the PFF no significant effect $(\mathrm{P} \geq 0.05)$, because the PFF to increase the biscuit water content was caused by dietary fiber content.

The ash of biscuits is higher when the addition of PFF and PSP more and more. The ash will decrease when the addition of PFF is getting smaller and PSP is getting lower. The highest ash from 3.5 to 4\%, with the addition of PFF 10-17.5 gr. The ash decreases around 3 values with the addition of PSP flour ranging from 85-90 gr, because an increase in PSP flour does not have a significant effect on the ash content of the biscuits. Ash is an element of minerals or inorganic substances contained in food (Monti, Virgilio, \& Ventury, 2018; Darman, Sidoine, \& Lendzemo, 2020).

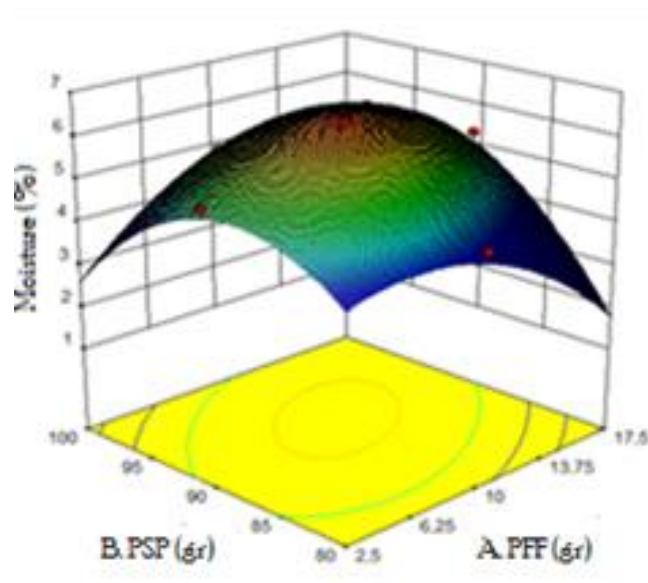

(A)

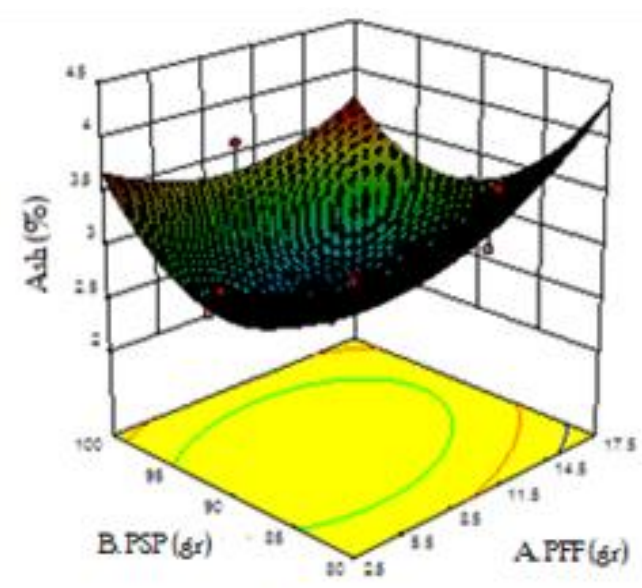

(B)

Figure 1.3D surface of moisture (A) and ash (B)

\section{Fat and protein}

Figure 2, shows the higher PSP with the addition of PFF, the fat will increase, while the fat decreases when PSP flour is getting lower with the addition of lower PFF. The highest fat ranges from 0.4 to $0.6 \%$, the addition of PFF values range from 6.25 to 17.5 gr with PSP range from 85 to $97 \mathrm{gr}$. The lowest fat ranges from $0.2 \%$, the addition of PFF range from 2.5 to $6.25 \mathrm{gr}$ with PSP range from 80-85 gr. The use of PFF has a small range and causes lower fat of PFF than PSP flour. The addition of margarine affects biscuit products because of the higher the addition of margarine the fat content increases. 


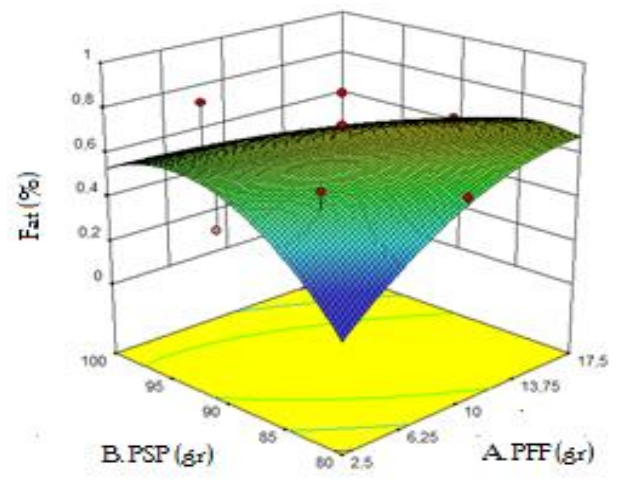

(A)

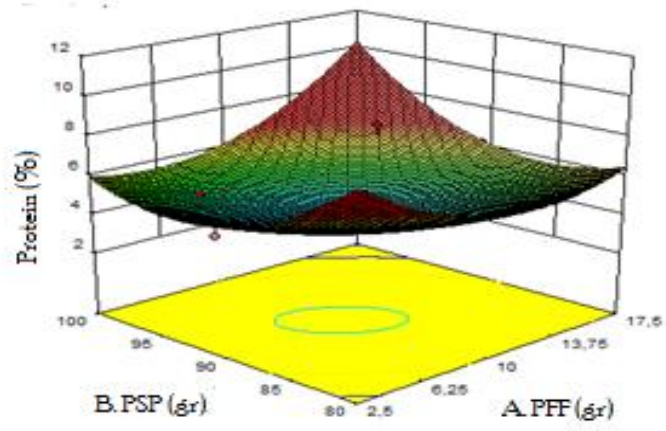

(B)

Figure 2. 3D surface of fat (A) and protein (B)

Figure 2, the higher PSP flour with the addition of more and more PFF, the value of the protein will increase. While protein decreases when PFF decreases with the addition of low PSP flour. The highest value ranges from 6-8 on the addition of 6.25-17.5 gr PFF and the addition of PSP flour ranging from 85-100 gr. While the value decreased around 4\% in the addition of 2.5 to 10 grams of PFF and the addition of PSP flour in the range of 80 - 90 grams. The (total) protein of the biscuits will be affected by the protein of the added PFF because it is known to have a high protein. The measured protein value will be even greater if the amount of water lost is greater (Debet \& Gidley, 2006). According to Olaoye, Onilude, \& Oladoye (2007), the measured protein depends on the number of ingredients added and is largely influenced by the moisture.

\section{Crude fiber, and antioxidant}

The 3D surface figure 3, showed that the higher PSP flour and the lower PFF crude fiber will increase. Whereas crude fiber will decrease when PFF gets lower and PSP flour gets lower. The highest value ranges from 1.4 to 1.8 in the addition of 6.25-17.5 grams of PFF and the addition of PSP 80-100 grams. While the value begins to decrease with the addition of 2.5 to 5.5 grams of PFF. The crude fiber of biscuits tends to increase with the increase in the addition of PSP flour because, during the roasting time, the resulting water will evaporate by heating so the biscuit's moisture decreases. In a product, if the moisture decreases, the crude fiber content increases (Kumar et al., 2015).

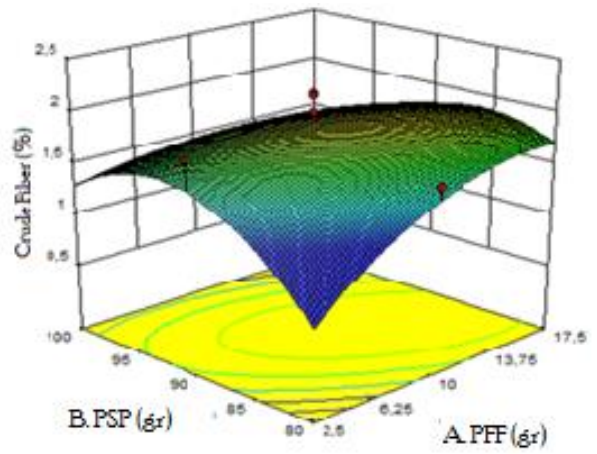

(A)

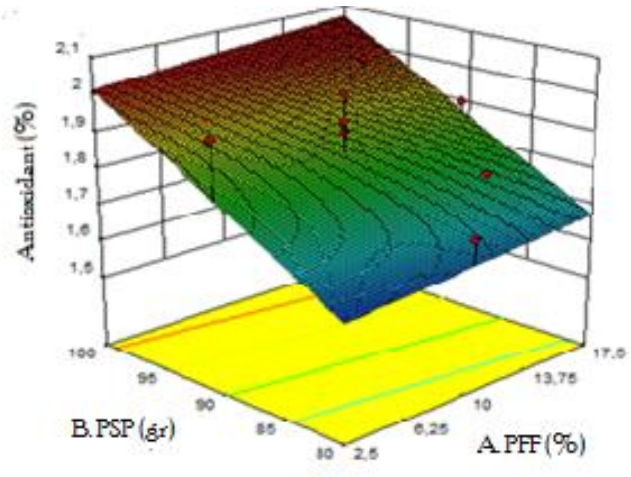

(B)

Figure 3. 3D surface of crude fiber (A) and antioxidant (B)

The antioxidant will increase when the addition of PSP more and more with a lower proportion of flour and antioxidants will decrease when the higher flour and less PSP flour. The highest 
antioxidants ranged from 1.9 - 2.00 which was achieved in the addition of PSP flour 95-100 grams while 1.7 - 1.8 was the lowest value of antioxidants achieved in 2.5 to 10 grams of PFF and the addition of proportions PSP flour 80-85 grams. Biscuits with PSP flour contain antioxidants, this is because PSP is rich in anthocyanin which acts as a stable coloring agent. Romadhoni et al., (2016), stated that PSP in terms of purple reaches $80 \%$ responding to the color of interest.

\section{Breaking strength}

The breaking strength (Figure 4) will increase when the addition of more flour with the proportion of PSP is increasing and the value of the breaking strength decreases when the proportion of PSP is increasing and the addition of less flour. The highest value of breaking strength ranged from 8 - 9 which was achieved in the addition of PFF around 13.75 -17.5 gr while 6-7 is the lowest value of breaking strength achieved in the proportion of PSP flour around 85-90 grams and the addition of PFF 56.25 - 11.5 gr. The breaking strength is increasing with the increase in the addition of PSP flour, the increase in the breaking strength is thought to be high in coarse fiber in the PSP flour. Crude fiber has a complex structure that makes purple sweet potato biscuits more difficult to break, because of the presence of crude fiber, it can absorb water so that it can disrupt the gelatinization process so that the gelatinization process becomes less perfect and causes higher fracture power (Kulthe, Thorat, \& Lande, 2017; Hadaegh et al., 2011).

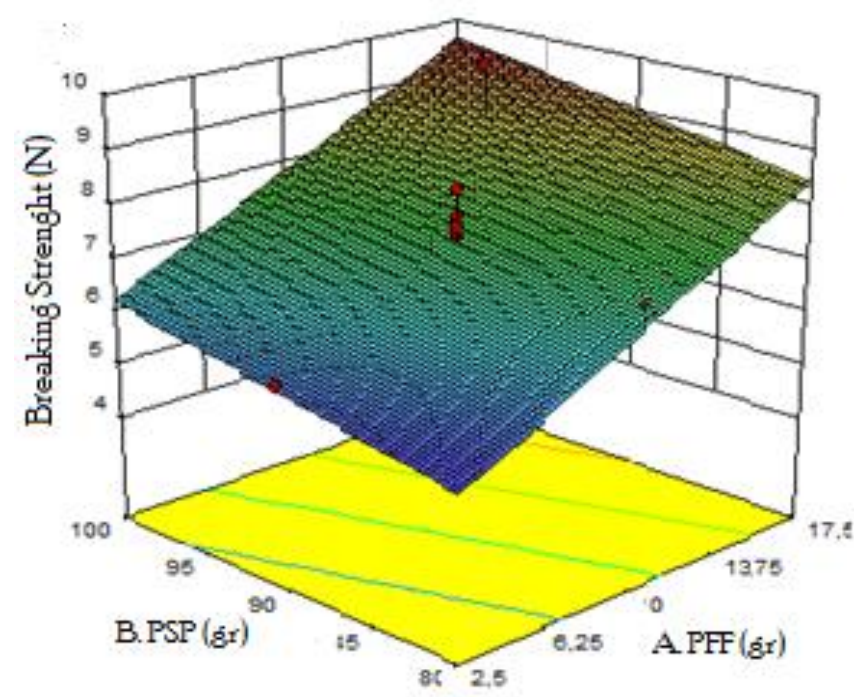

Figure 4. 3D surface of breaking strength

\section{Colour}

Figure 5 showed that the more increased the addition of PFF and the higher PSP flour, the higher of color analysis of $L^{*}$. The color of $\mathrm{L}^{*}$ will decrease when the addition of less PFF and the lower PSP. The high favorite ranges from $34-34.5$ on the addition of $14.5-17.5$ grams PFF and PSP between 90-100 gr. The average brightness of PFF biscuits and PSP flour ranged from 32.6 to 35.4. The brightness (L) of biscuits tends to decrease with the increasing proportion of added PFF but will tend to increase along with the increasing proportion of PSP flour addition. On increasing the brightness level increases.

The less addition of PFF and lower PSP flour, the more color analysis of a *, will decrease when the addition of more PFF and lower PSP flour. The high preferred ranges from 10-15 in the addition of 2.5 to 13.75 grams of PFF and PSP flour between 80 - 90 gr. The average brightness of the biscuit and PSP flour ranges from 5-15. The reddish level $a^{*}$ biscuits tend to increase with a 
greater proportion of PFF but will tend to decrease with the increasing proportion of PSP flour. The addition of biscuits has a significant effect on the level of redness $\left(a^{*}\right)$ biscuits.

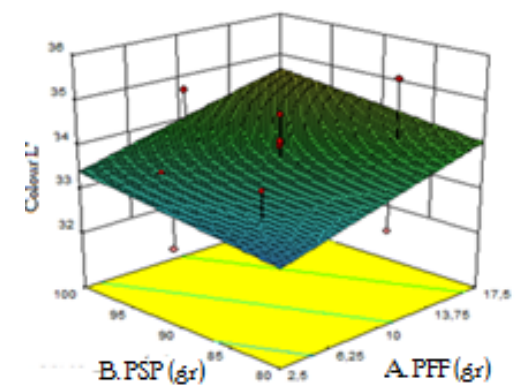

(L)

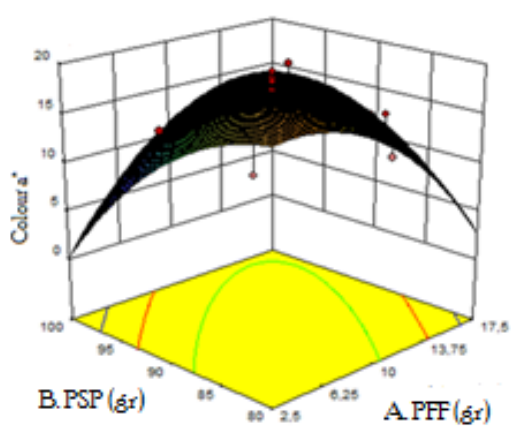

( $\left.a^{*}\right)$

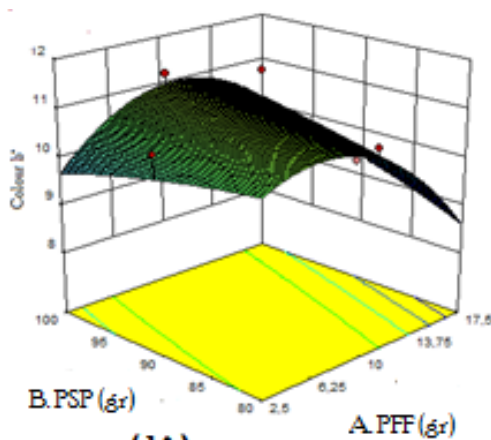

(b*)

Figure 5.3D surface of the color biscuit

\section{Optimization}

Table 2, showed the desirability value is close to one, the higher the accuracy value, so that it can be concluded that the condition of the proportion of PFF $2.5 \%$ with the addition of $99.888 \%$ PSP flour will produce biscuit products that have characteristics that match the optimization target of $76.3 \%$, and predicted to produce biscuits with a moisture content of $2.658 \%$ and antioxidants $2.012 \%$.

Table 2. Response value $\left(\mathrm{Y}^{\wedge}\right)$ at optimum condition

\begin{tabular}{cccc}
\hline No. & Response & Value $\left(\mathbf{y}^{\wedge}\right)$ & Real Value (Laboratory test) \\
\hline 1. & Moisture & 2.658 & 6.18 \\
2. & Ash & 3.666 & 2.63 \\
3. & Fat & 0.539 & 0.87 \\
4. & Protein & 5.952 & 3.26 \\
5. & Crude fibre & 1.292 & 2.15 \\
6. & Antioxidant & 2.012 & 1.65 \\
7. & 6.228 & 7.43 \\
8. & Breaking strength & 33.407 & 34.0 \\
9. & Colour $\mathrm{L}^{*}$ & 0.354 & 17.4 \\
10. & Colour $\mathrm{a}^{*}$ & 9.692 & 10.8 \\
\hline
\end{tabular}

Optimum conditions in the research process of making biscuits are by adding $2.5 \mathrm{gr}$ of PFF and PSP flour $99.88 \mathrm{gr}$. The optimum condition results in the highest addition of PFF, because PFF increases the biscuit's moisture due to crude fiber, therefore PFF can bind large water. Yang et al., (2017), reported that the water-bound to crude fibers is difficult to be released even with heating. Whereas the PSP has a water absorption of $1.69 \mathrm{ml} / \mathrm{g}$ and it has a solubility of $17.06 \%$ as the ability of flour to dissolve in water (Tang et al., 2017) 
The addition of PSP flour at optimum conditions was 99.988 in the process of making biscuits. The addition of PSP flour to replace wheat flour with different ratios (100: 0, 90:10, and 70:30) used in making biscuits, producing biscuits received well from all ratios of flour: PSP flour. Based on the analysis of protein and fat decreased, for crude fiber increased the higher of PSP flour substitution.

\section{Conclusion}

The best treatment has obtained the PFF: PSP flour (10:90) with $6.18 \%$ of moisture, $2.63 \%$ of ash, $0.87 \%$ of fat, $3.26 \%$ of protein, $2.15 \%$ of crude fiber, antioxidant $1.65 \%$, breaking strength $7.43 \mathrm{~N}$, the color of $\mathrm{L} * 34.0, \mathrm{a} * 17.4, \mathrm{~b} * 10.8$. The optimum conditions in making biscuits were obtained PFF at 2.5 gr and 99.888 gr of PSP with the highest desirability of 0.763 .

\section{Acknowledgment}

We would like to thanks Allah SWT and parents.

\section{References}

AOAC, (2000). Official methods of analysis of AOAC International 18th edition. Gaithersburg, Maryland, USA.

AL-Ansi, W., Mahdi, A. A., Li, Y., Qian, H., \& Wang, L. (2018). Optimization and acceptability evaluation of shapporah biscuits formulated by different ingredients: Using Response Surface Methodology (RSM). Journal of Food and Nutrition Research, 6, (3), 192-199.

Cevallos-Casals, B. A., \& Cisneros-Zevallos, L. A. (2002). Bioactive and functional properties of purple sweetpotato (Ipomoea batatas (L.) Lam). Acta Hort 583, 195-203.

Darman, R. D.,Sidoine, M. B., \& Lendzemo, V. W. (2020). Development of sorghum-based shortbread biscuits from "muskwari” flour. Food Science \& Nutrition, DOI: $10.1002 /$ fsn3.1574.

Debet, M. R., Gidley, M. J. (2006). Three classes of starch granule swelling: Influence of surface proteins and lipids. Carbohydrate Polymer, 64, 452-465.

Hadaegh, H., Tarzi, B. G., Ardabili, S. M. S., Bassiri, A., \& Khani, S. K. (2011). Effect of DATEM and fat reduction in semi-hard biscuits using RSM. Advances in Environmental Biology, 5(8), 2451-2458.

Jariyah, Azkiyah, L., Widjanarko, S.B., Estiasih, T., Yuwono, S.S., \& Yunianta, (2013). Hypocholesterolemic effect of pedada (Sonneratia caseolaris) fruit flour in wistar rats. International Journal of Pharm Tech Research, 5(4), 1619-1627.

Jariyah, Widjanarko , S.B., Yunianta , Estiasih , T., \& Sopade, P.A. (2014). Pasting properties of pedada (Sonneratia caseolaris) fruit flour and wheat flour mixtures. Proceedings ASIAHORCS 2013. LIPI Press, member of Ikapi, Jakarta. p. 335-340.

Kulthe, A. A., Thorat, S.S., \& Lande, S.B. (2017). Evaluation of physical and textural properties of cookies prepared from pearl millet flour. Int.J.Curr.Microbiol.App.Sci, 6(4), 692-701.

Kumar, K. A., Sharma, G. K., Khan, M. A., \& Semwal, A. D. (2015). Optimization of multigrain premix for high protein and dietary fibre biscuits using Response Surface Methodology (RSM). Food and Nutrition Sciences, 6, 747-756.

Li, A., Wang, B., Xiao, R., He, S., An, X., He, Y., Wang, C., Yin, S., Shi, X., \& He, J. (2019). Research advances of purple sweet potato anthocyanins: extraction, identification, stability, bioactivity, application, and biotransformation. Molecules, $24,3816$. doi:10.3390/molecules24213816.

Monti, A., Virgilio, N. D., \& Venturi, G. (2008). Mineral composition and ash content of six major energy crops. Biomass And Bioenergy, $32,216-223$.

Neela, S., \& Fanta, S.W. (2019). Review on nutritional composition of orange-fleshed sweet potato and its role in management of vitamin A deficiency. Food Science and Nutrition, 7, 1920-1945.

Nishino, H., Tokuda, H., Satomi, Y., Masuda, M., Onouka, M., Yamaguchi, S., Takayasu, J., Tsuruta, J., Takemura, M., Ii, T., Ichiishi, E., Kuchide, S., Okuda, M., \& Murakoshi, M. (2000). Cancer chemoprevention by phytochemicals and their related compounds. Asian Pacific J Cancer Prev, 1, 49-55.

Olaoye O. A , Onilude A. A., \& Oladoye C. 0 (2007). Breadfruit flour in biscuit making: effects on product quality . African Journal of Food Science, 020-023,

Romadhoni, A. R., Afrianto, E., Pratama, R. I., \& Grandiosa, R. (2016). Extraction of snakehead fish [Ophiocephalus striatus(Bloch, 1793)] into fish protein concentrate as albumin source using various solvent. Aquatic Procedia, 7, 4 - 11. 
Suda, I., Oki, T., Masuda, M., Kobayashi, M., Nishiba, Y., \& Futura, S. (2003). Physiological functionality of purpule-fleshed seet potatoes containing anthocyanins and their utilization in foods. JARQ, 37 (3), 167-173.

Singh, P., Singh, R., Jha, A., Rasane, P., \& Gautam, A. K. (2015). Optimization of a process for high fibre and high protein biscuit. J Food Sci Technol, 52(3), 1394-1403.

Singh, S. P., \& Yadav, N. (2018). Development and evaluation of sugar free biscuit prepared by fenugreek seed powder and natural sweetener stevia and process optimization by response surface methodology. Intl. J. Food. Ferment. Technol, 8(2), 191-200.

Tang, C., Sun, J., Zhou, B., Jin, C., Liu, J., Kan, J., Qian, C., \& Zhang, N. (2017). Effects of polysaccharides from purple sweet potato on immune response and gut microbiota composition in normal and cyclophosphamide treated mice. Food Funct, 2018(9), 937950. DOI: 10.1039/C7F001302G.

Wicaksono. L. A., Susiloningsih, E. K. B., \& Susanti, M. A. (2019). Proximate analysis of food bar made from pedada fruit (Sonneratia caseolaris) enhanced with gembili flour and mung bean flour as an alternative to emergency food. International Joint Conference on Science and Technology, 119-124.

Yang, Y., Ma, S., Wang, X., and Zheng, X. (2017). Modification and Application of Dietary Fiber in Foods. Journal of Chemistry, $2017,8$. 